\title{
Macroscopic Morphometric Analysis of Genital Organs of Rabbit does with Differing Parturitions at 24 Hours Post-weaning
}

\author{
Análisis Morfométrico Macroscópico de Órganos Genitales de \\ Conejas con Diferentes Partos a las 24 Horas Post-destete
}

\author{
Jesús Aragón-Hernández*; Fernando Iván Flores-Pérez**; Claudia Hallal-Calleros** \& Mario Pérez-Martínez ${ }^{* * *}$
}

ARAGÓN-HERNÁNDEZ, J.; FLORES-PÉREZ, F. I.; HALLAL-CALLEROS, C. \& PÉREZ-MARTÍNEZ, M. Macroscopic morphometric analysis of genital organs of rabbit does with differing parturitions at 24 hours post-weaning. Int. J. Morphol., 31(3):991996, 2013.

SUMMARY: The purpose of this study was to analyze the macroscopic morphometry of the ovaries, uterus and vagina in rabbit does in the first, second and third parturition at 24 hours post-weaning in order to determine if there are differences between parturitions. Weaning of the litter was performed at 30 days post-partum and 24 hours later the does were euthanized. Right and left ovaries, uterine horns-cervix and vagina were removed, and the length of each one was measured. Significant differences were found in the average of the right ovary length between the first group with respect to second and third parturition group ( $\mathrm{P} \leq 0.05$ and $\mathrm{P} \leq 0.01)$. Also, left ovary length was different between the first and second with respect to third parturition group $(\mathrm{P}<0.001)$. Average total ovary length increased significantly as the number of parturitions increased in second and third parturition groups $(\mathrm{P} \leq 0.01$ and $\mathrm{P} \leq 0.001)$. The weight of the left and right ovaries was higher in does in their second and third parturition when compared to those in their first $(\mathrm{P} \leq 0.5$; $\mathrm{P} \leq 0.01)$. The average total ovary weight increased significantly as the number of parturitions in second and third parturition groups ( $\mathrm{P} \leq 0.001)$. The length of the left and right uterine horn-cervix of the rabbits after second and third parturition decreased when compared to that of females in their first parturition $(\mathrm{P} \leq 0.05 ; \mathrm{P} \leq 0.001)$. The average total uterine horns-cervix length decreased significantly as the number of parturitions in second and third parturition groups $(\mathrm{P} \leq 0.001)$. Furthermore, vagina length in females in their third parturition was greater than that of first and second parturition $(\mathrm{P} \leq 0.01)$. The color of the vulva of the majority of females in their first parturition $(3 / 4)$ was pale pink while. In contrast, the majority of females in their second parturition (3/4) had their vulva intensely red. All of the females (4/4) in the third parturition group had their vulva intensely red. We conclude that in female rabbits the macroscopic morphometric characteristics of ovaries, uterus and vagina, at 24 hours post-weaning vary according to the number of parturitions.

KEY WORDS: Rabbit doe; Post-weaning; Morphometry; Genital organs.

\section{INTRODUCTION}

During postpartum uterine involution, tissue remodeling events occur, and a decreased in vascularity and myometral cell number. These changes are leading to the restoration of the function, size and anatomical position of the genital organs, so that the doe is in the possibility of start another pregnancy. The reproductive function depends not only on hormonal environment but also on the animal nutrition state (Ferguson et al., 2006).

It has been shown that lactating does with increased number of parturitions that receive a greater amount of fat in their diet have a larger litter size and heavier kits (Pascual et al., 1998). It has also been proposed in rabbits that short feeding periods with high levels of energy can improve reproductive performance (Meshreky et al., 2012). Moreover, in the post-weaning period, endocrine changes occur that induce changes in sexual behavior resulting in a greater or lesser male receptivity that finally impacts the number of weaned rabbits (Knobil, 2006).

In intensive and semi-intensive rabbit breeding systems the time at which a new gestation period starts after parturition is very short. Frequently breeding is carried out at day 11 post-partum, notwithstanding that the doe is

\footnotetext{
Facultad de Agrobiología. Universidad Autónoma de Tlaxcala, Xalpatlahuaya, Huamantla, Tlaxcala, México.

** Facultad de Ciencias Agropecuarias. Universidad Autónoma del Estado de Morelos, México.

**** Facultad de Medicina Veterinaria y Zootecnia. Universidad Nacional Autónoma de México.
} 
lactating (Rebollar et al., 2009). The inhibitory effect of lactation on the reproductive function of the domestic rabbit doe is well known (Rebollar et al., 1992), nevertheless, until now the effect of weaning on the morphometric characteristics of ovaries, uterus and vagina in does with different parturitions has not been examined. The rabbit doe reproductive tract has been largely studied in some aspects, for example, to determine hormonal mechanisms of action due to the fact that rabbits present reflex ovulation (Anzaldúa et al., 2007), but it has been scarcely studied about the reproductive morphometric features. Taking into account the above, the practical application of the study of the length dynamics of structures such as the ovaries and uterine horns in the female domestic, would help in the design of weaning programs in which the right time to carry out this practice is known, in order to not to interfere with ovarian physiology and optimize production, in addition to recognize with morphometry the useful life of rabbits for breeding. The purpose of this study was to analyze the macroscopic morphometric characteristics of ovaries, uterus and vagina of rabbit does in their first, second and third parturition at 24 hours post-weaning in order to determine the differences between parturitions.

\section{MATERIAL AND METHOD}

Twelve adult New Zealand breed does were included in this study, non-pregnant, lactating, clinically healthy, obtained from a commercial farm located in Tlaxcala, Mexico. They were kept under a controlled light-darkness cycle (16 h light:8 h darkness) in individual metal cages. The does had free access to a commercial pellet diet (Purina $\left.{ }^{\circledR}\right)(18 \%$ crude protein and $15.5 \%$ crude fiber) and water ad libitum. All efforts were made to minimise both animal suffering and the number of animals used. Three groups were formed ( $\mathrm{n}=4$ per group) with lactating females in their first, second or third parturition. Average live weight of females in each group was $3.025 \pm 0.04,3.31 \pm 0.194$ and $3.52 \pm 0.32 \mathrm{Kg}$ respectively. None of the lactating females used in this study was bred. Kit weaning was carried out at day 30 post-partum. Females were euthanized 24hours after weaning by neck-breaking desensitization and immediately cutting the jugular vein. The study carried out followed Mexican Law for the Protection of wild and domestic animals, and the Mexican Official Standard NOM-033-ZOO-1995.

Afterwards, a mid-line incision was done in order to remove the right and left ovaries (Ovarium [dextrum et sinistrum]) left and right uterine horns with cervix (Cornu uteri [dextrum et sinistrum] - Cervix uteri), and vagina
(ICVGAN, 2005). Length of the removed organs was immediately measured using a Vernier scale after the anatomical limits of each were determined, while ovary weight was taken using an analytical balance.

Prior to slaughter, color and swelling of the vulva were inspected as an indicator of the reproductive stage. Red coloration of the vulva is associated with a predominantly estrogenic influence accompanied with sexual receptivity for the male (Díaz et al., 1988). To compare the results of the measurements of each genital organ between the three experimental groups we used an ANOVA test and then a Tukey-Kramer test. All results are shown as the mean \pm SEM, and statistical significance set at $P \leq 0.05$; $\mathrm{P} \leq 0.01$ and $\mathrm{P} \leq 0.001$.

\section{RESULTS}

As shown in Figure 1A, significant differences were found in the average of the right ovary length between the first group with respect to second and third parturition group $(\mathrm{P} \leq 0.05$ and $\mathrm{P} \leq 0.01$, respectively). Also, average left ovary length was significantly different between the first and second with respect to third parturition group $(\mathrm{P}<0.001)$ (Fig. 1B). On the other hand, the average total ovary length (right and left) increased significantly as the number of parturitions increased in second and third parturition groups ( $\mathrm{P} \leq 0.01$ and $\mathrm{P} \leq 0.001$, respectively) (Fig. 2).

Average weight of the left and right ovaries was significantly higher in does in their second and third parturition when compared to those in their first $(\mathrm{P} \leq 0.5$; $\mathrm{P} \leq 0.01$ ) (Fig. 3A and B). On the other hand, the average total ovary weight (right and left) increased significantly as the number of parturitions in second and third parturition groups ( $\mathrm{P} \leq 0.001)$ (Fig. 4).

Average length of the left (LUHL) and right (RUHL) uterine horn-cervix of the rabbits after second and third parturition decreased significantly when compared to that of females in their first parturition ( $\mathrm{P} \leq$ 0.05; $\mathrm{P} \leq 0.001$ ) (Figs. 5A and B).

The average total uterine horns-cervix length (right and left) decreased significantly as the number of parturitions in second and third parturition groups $(\mathrm{P} \leq 0.001)$ (Fig. 6).

Furthermore, average vagina length in females in their third parturition was greater than that of first and second parturition $(\mathrm{P} \leq 0.01)$. 
A

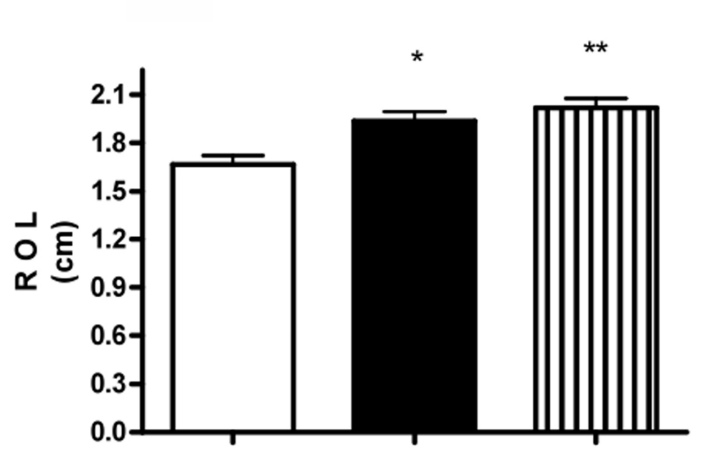

B

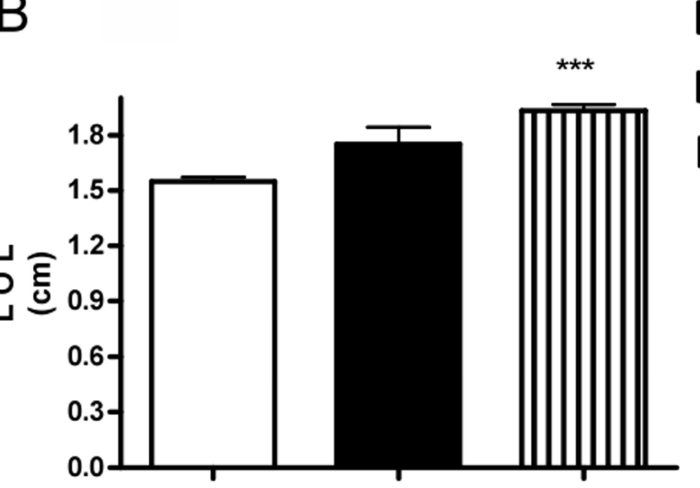

Fig. 1. A. Right Ovary Length (ROL) and B. Left Ovary Length (LOL) in New Zealand breed does with different parturition number at 24-hours post-weaning. Values are expressed as mean \pm SE. Significant different was found between groups. ANOVA Test and Tukey- Kramer's post-test ( $* \mathrm{P} \leq 0.05, * * \mathrm{P} \leq 0.01$, *** $\mathrm{P} \leq 0.001)$.

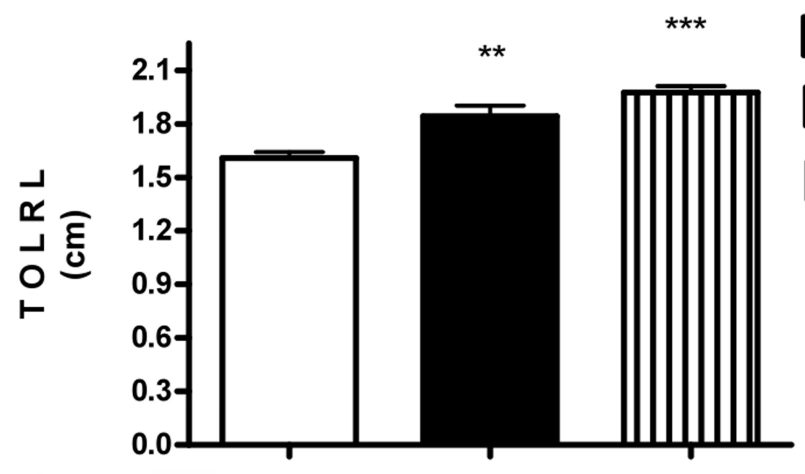

A

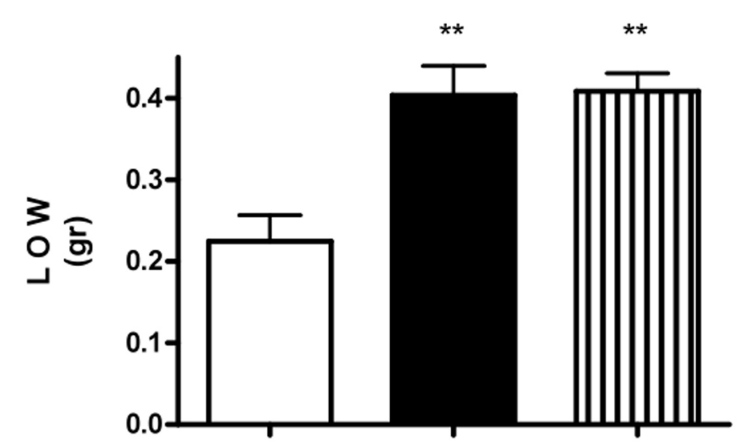

$\square$ First

$\square$ Second

III Third
Fig. 2. Total Ovary Length Right and Left (TOLRL) in New Zealand breed does with different parturition number at 24-hours post-weaning. Values are expressed as mean \pm SE. Significant different was found between groups. ANOVA Test and Tukey- Kramer's post-test. $(* * \mathrm{P} \leq 0.01, * * * \mathrm{P} \leq 0.001)$

Fig. 3. A. Left Ovary Weight (LOW) and B Right Ovary Weight (ROW) in New Zealand breed does with different parturition number at 24-hours post-weaning. Values are expressed as mean $\pm \mathrm{SE}$. $* \mathrm{P}<0.05 * * \mathrm{P}<0.01$. Differences were found between groups. ANOVA Test and Tukey- Kramer post-test. ( $* \mathrm{P} \leq 0.05 * * \mathrm{P} \leq 0.01)$.

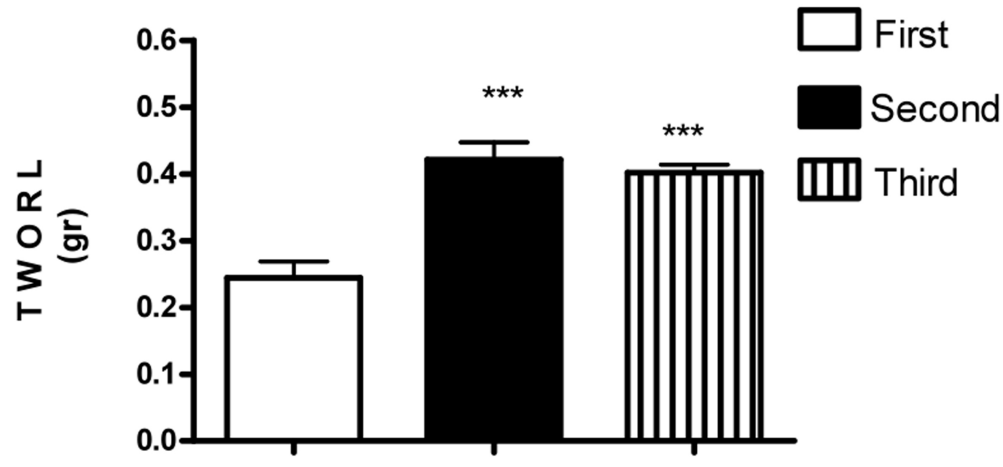

Fig. 4. Total Weight of Ovaries Right and Left (TWORL) in New Zealand breed does with different parturition number at 24-hours post-weaning. Values are expressed as mean \pm SE. Differences were found between groups. ANOVA Test and Tukey- Kramer posttest. $(* * * \mathrm{P} \leq 0.001)$. 
A

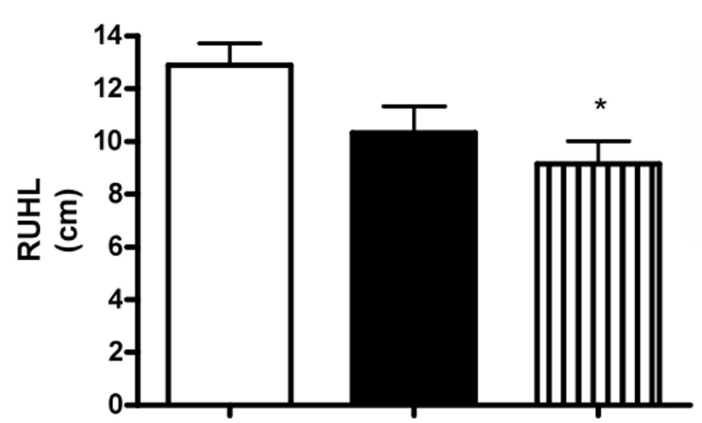

B

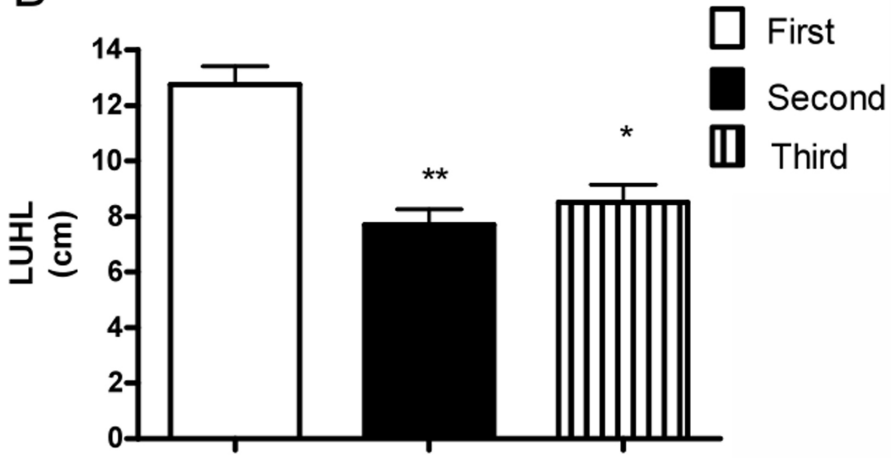

Fig. 5A. Right Uterine Horn-Cervix Length (RUHL) and B. Lett Uterine Horn-Cervix Length (LUHL) in New 'Zealand breed does with different parturition number at 24-hours post-weaning. Values are expressed as mean \pm SE. Significant different was found between groups. ANOVA Test and Tukey- Kramer's post-test. (* $\mathrm{P} \leq 0.05$, ** $\mathrm{P} \leq 0.01$ ).

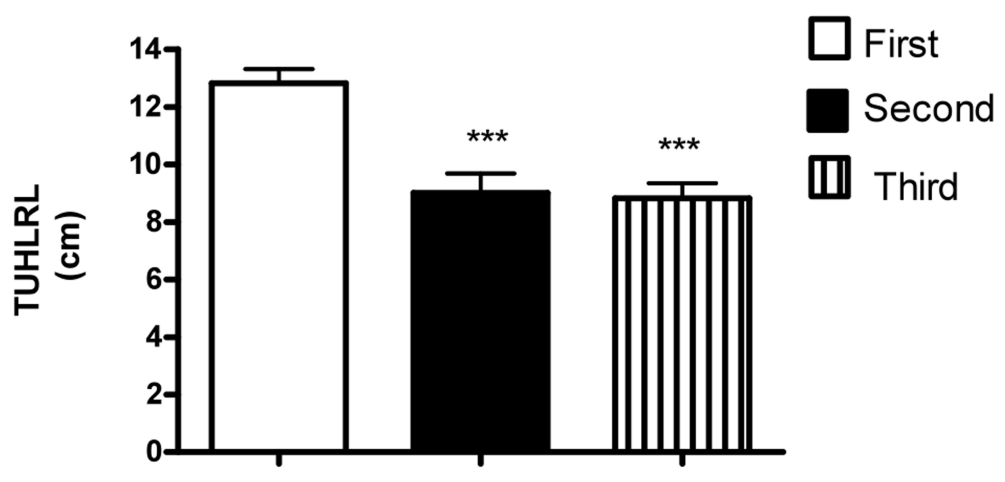

Fig. 6. Total Uterine Horns-cervix Length Right and Left (TUHLRL) in New Zealand breed does with different parturition number at 24-hours postweaning. Values are expressed as mean \pm SE. Differences were observed between first and the other two groups. ANOVA Test and Tukey- Kramer posttest. .(*** $\mathrm{P}<0.001)$.

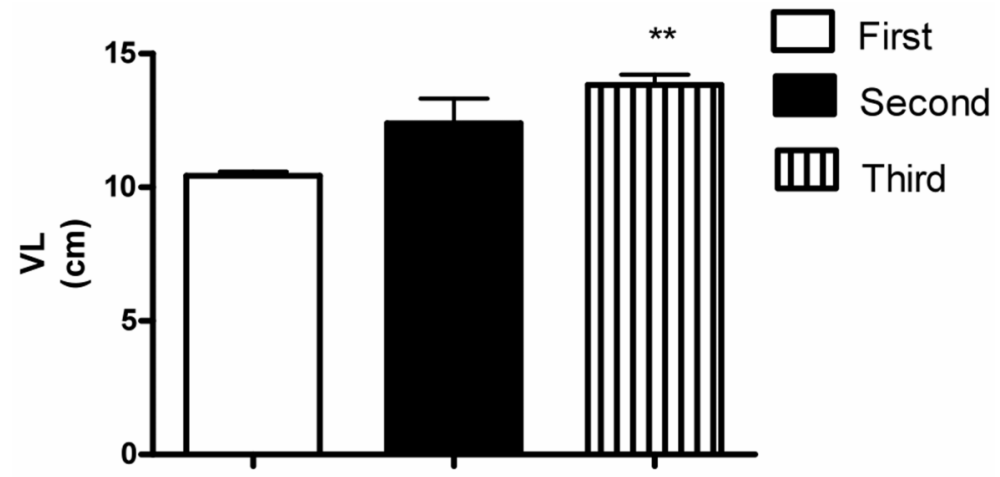

Fig. 7. Vagina Length (VL) in New Zealand breed does at 24-hours post-weaning. Values are expressed as mean \pm SE. Difference was observed between first and third group. ANOVA Test and Tukey- Kramer post-test. (** $\mathrm{P}<0.01)$.

Is important to highlight that the color of the vulva of the majority of females in their first parturition (3/4) was pale pink while, in the remaining doe it was red. In contrast, the majority of females in their second parturition (3/4) had their vulva intensely red and the remaining doe, pale pink. All (4/4) of the females in the third parturition group had their vulva intensely red. 


\section{DISCUSSION}

In this study we found that at 24-hours post-weaning ovary length and weight in females in their second and third parturition were greater than that of females in their first parturition.

It is possible that the greater ovary length in females in their second and third parturition when compared to females in their first parturition is due to an increased ovary follicle development activity in the hours after weaning. It has been suggested that in primiparous does lactation concurrent with pregnancy affects early ovary follicle development (Fortun-Lamothe et al., 2000). With this information at hand it was decided that this study would utilize lactating females that were not pregnant in order to be able to assess only the effect of weaning on uterine and ovarian morphometric characteristics.

In contrast average left and right horn-cervix length of females in their second and third parturition decreased significantly in comparison to that of females in their first parturition.

Our results indicate that the changes observed at 24 hours post-weaning in ovary and uterine morphometric characteristics between females in their first parturition and those in their second or third have a differential behavior. Furthermore, average ovary length in females in their second and third parturition increased in relation to that of females in their first parturition, while average uterine length decreased in females in their second and third parturition. It is known that the concentration of $17 ß$ estradiol increases after weaning and that the proportion of females that show signs of estrus increases (Ubilla et al., 2000). These hormonal and behavioral changes associated to the stimulation by weaning clearly reflect the importance of the time at which weaning is carried out, and its effect on ovary follicle development as well as the inhibitory effect that it has on ovarian activity. On the other hand, the pale pink color of the vulva of the majority (3/4) of females at first parturition before euthanasia suggests that estrogen influence on the tissues was lacking. This observation could also be related to the reduced length and weight of ovaries in first-parturition does. It is noteworthy that in females in their second and third parturition the proportion of vulva coloring was inverted, the majority were red (3/4) coinciding with a greater average ovary length. This behavior in morphometric dynamics of the ovary in relation to the color of the vulva can signal the effect that the weaning stimulus has and the different way in which does respond depending if they are primiparous or multiparous. Furthermore, the intense red of the vulva of the second and third parturition females suggest that they were receptive to males, as shown in previous studies (Díaz et al.; Cano et al., 2005; Ola \& Oyegbade, 2012).

Estrogens have morphogenic activity on ovaries and uterus (Bai et al., 2000), therefore increase in their concentration induces an increase in cell proliferation in the reproductive tissue. This has been confirmed in studies in which it was shown that at the start of the reproductive stage of the young doe the dimensions of the genital organs increase, mainly in the transitional stage before puberty, in relation to the female's live weight (Aragón et al., 2010).

We conclude that the macroscopic morphometric characteristics of the ovaries and uterus of female breeder rabbits at 24 hours post-weaning vary according to the number of parturitions indicating the need for further studies on the impact that the time of weaning, beginning from the first parturition on, has on the subsequent productivity of the doe.

\section{ACKNOWLEDGEMENTS}

This study was financed in part by the PAPIME (PE201711) project of DGAPA, UNAM. The authors wish to thank the Faculty of Agrobiology of the Autonomous University of Tlaxcala for the facilities provided for carrying out this work. The corresponding author wishes to thank the National Autonomous University of Mexico for the support provided for finishing this study during a sabbatical period.

ARAGÓN-HERNÁNDEZ, J.; FLORES-PÉREZ, F. I.; HALLAL-CALLEROS, C. \& PÉREZ-MARTÍNEZ, M. Análisis morfométrico macroscopico de órganos genitales de conejas con diferentes partos a las 24 horas post-destete. Int. J. Morphol., 31(3):991-996, 2013.

RESUMEN: El propósito de este estudio fue analizar la morfometría macroscópica de los ovarios, útero y vagina en conejas de primero, segundo y tercer parto a las 24 horas post-destete con el propósito de determinar si existen diferencias entre los partos. El destete de la camada se realizó a los 30 días después del parto y 24 horas después fueron eutanasiadas. De cada animal se removieron los ovarios derecho e izquierdo, cuernos-cuello uterinos derecho e izquierdo y la vagina y se midió la longitud de cada uno de los órganos genitales. Se encontraron diferencias significativas en la longitud del ovario derecho entre el grupo de primer parto con respecto al de segundo y tercer parto $(\mathrm{P} \leq 0,05$ y $\mathrm{P} \leq 0,01)$. Además, la longitud media de ovario izquierdo fue significativamente diferente entre el grupo de primero y segundo parto con respecto al de tercer parto $(\mathrm{P}<0,001)$. La longitud total 
de los ovarios aumentó con el número de partos y fue mayor en los grupos de segundo y tercer parto $(\mathrm{P} \leq 0,01 \mathrm{y} \mathrm{P} \leq 0,001)$. El peso de los ovarios derecho e izquierdo fue mayor en el grupo de segundo $\mathrm{y}$ tercer parto al compararlo con el de primero parto $(\mathrm{P} \leq 0,5 ; \mathrm{P} \leq$ 0,01). Por otra parte, el peso total de los ovarios aumentó en los grupos de segundo y tercer parto $(\mathrm{P} \leq 0,001)$. La longitud del cuerno-cuello uterino izquierdo y derecho de los grupos de segundo y tercer parto disminuyó al compararlo con el de las hembras de primer parto $(\mathrm{P} \leq 0,05 ; \mathrm{P} \leq 0,001)$. La longitud total del cuernocuello uterino izquierdo y derecho disminuyó significativamente en las hembras de segundo y tercer parto $(\mathrm{P} \leq 0,001)$. La longitud de la vagina de hembras de tercer parto fue mayor que la de primero y segundo parto $(\mathrm{P} \leq 0,01)$. El color de la vulva de la mayoría de las hembras de primer parto (3/4) fue rosa pálido. En contraste, la mayoría de las hembras en su segundo parto (3/4) presentaron vulva de color rojo intenso. Todas las hembras del grupo de tercer parto (4/4) presentaron vulva de color rojo intenso. Se concluye que las características morfométricas macroscópicas de los ovarios, úteros y vagina de la coneja reproductora a las 24 horas post-destete varían con relación al número de partos.

PAlabras Clave: Coneja; Post-destete; Morfometría; Órganos genitales.

\section{REFERENCES}

Anzaldúa, S. R.; Camacho-Arroyo, I.; Reyna-Neyra, A.; PérezMartínez, M. \& Cerbón, M. A. Regional differences in expression of progesterone receptor in oviduct and uterus of rabbit during early pregnancy. Comp. Biochem. Physiol. A Mol. Integr. Physiol., 147(3):685-90, 2007.

Aragón, H. J.; Suárez, S. J. \& Pérez-Martínez, M. Morphometric characteristics of female reproductive organs of New Zealand rabbits with different body weight in peripuberal period of transition. Vet. Mex., 41(3):211-8, 2010.

Bai, W.; Oliveros-Saunders, B.; Wang, Q.; Acevedo-Duncan, M. \& Nicosia, S. V. Estrogen stimulation of ovarian surface epithelial cell proliferation. In Vitro Cell Dev. Biol. Anim., 36(10):657-66, 2000.

Cano, P.; Jiménez, V.; Álvarez, M. P.; Alvariño, M.; Cardinali, P. \& Esquifino, A. I. Effect of litter separation on 24-hour rhythmicity of plasma prolactin, follicle-stimulating hormone and luteinizing hormone levels in lactating rabbit does. $J$. Circadian Rhythms, 3:9, 2005.

Díaz, P.; Gosalvez, L. F. \& Rodríguez, J. M. Sexual behaviour in the postpartum period of domestic rabbits. Anim. Reprod. Sci., 17(3-4):251-7, 1988.

Ferguson, E. M.; Slevin, J.; Edwards, S. A.; Hunter, M. G. \& Ashworth, C. J. Effect of alterations in the quantity and composition of the pre-mating diet on embryo survival and foetal growth in the pig. Anim. Reprod. Sci., 96(1-2):89-103, 2006.
Fortun-Lamothe, L.; Powers, S.; Collet, A.; Read, K. \& Mariana, J. C. Effects of concurrent pregnancy and lactation in rabbit does on the growth of follicles in daughters ovaries. World Rabbit Sci., 8:33-40, 2000.

ICVGAN (International Committee on Veterinary Gross Anatomical Nomenclature). Nomina Anatomica Veterinaria. $5^{\text {th }}$ ed. Knoxville, World Association of Veterinary Anatomists, 2005.

Knobil, N. Physiology of Reproduction. $3^{\text {rd }}$ ed. San Diego, Academic Press, 2006.

Meshreky, S. Z.; Ashmawy, N. A.; Ali Kh. A. A. \& Arafa, M. M. Feeding regimen during rearing in female rabbits under Egyptian environmental conditions: effect on ovarian activity and embryo quality production. World Rabbit Science Association Proceedings 10 th World Rabbit Congress September 3 - 6, Sharm El- Sheikh -Egypt, 2012.

Ola, I. \& Oyegbade, M. Buck effect on rabbit oestrous: vulva colour, vaginal lumen cells and ovarian follicle populations. World Rabbit Sci., 20:71-9, 2012.

Pascual, J. J.; Cervera, C.; Blas, E. \& Fernández-Carmona, J. Effect of high fat diets on the performance and food intake of primiparous and multiparous rabbit does. Anim. Sci., 66(2):4919, 1998

Rebollar, P. G.; Ubilla, E.; Rodríguez, J. M.; Illera, J. C. \& Silvan, G. Influencia del nivel de receptividad sexual sobre el estradiol plasmático y la respuesta ovulatoria durante el posparto en la coneja. Rev. Esp. Fisiol., 48(1):13-7, 1992.

Rebollar, P. G.; Pérez-Cabal, M. A.; Pereda, N.; Lorenzo, P. L.; Arias-Alvarez, M. \& García-Rebollar, P. Effects of parity order and reproductive management on the efficiency of rabbit productive systems. Livest. Sci., 121(2-3):227-33, 2009.

Ubilla, E.; Rebollar, P. J.; Pazo, D.; Esquifino, A. \& Alvariño, J. M. Effects of doe-litter separation on endocrinological and productivity variables in lactating rabbits. Livest. Prod. Sci., 67(1-2):67-74, 2000.

\section{Correspondence to:}

Dr. Mario Pérez Martínez.

Profesor Titular, Departamento de Morfología

Laboratorio de Biología Tisular de la Reproducción "Rosa E. Lavielle"

Facultad de Medicina Veterinaria y Zootecnia

Universidad Nacional Autónoma de México

Avenida Universidad 3000

México, D.F. 04510

MÉXICO

Received: 21-11-2012

Tel.: +525556225893

Accepted: 19-05-2013

\section{Email: perezmtzmario@yahoo.com.mx}

